\title{
THE SOUTH CHINA SEA: A PLACE OF RIVALRY AND POWER MANAGEMENT ${ }^{1}$
}

\author{
Agata Wiktoria Ziętek \\ Maria Curie-Skłodowska University in Lublin, \\ Faculty of Political Science, Department of International Relations \\ e-mail: wiktoriazietek@gmail.com
}

\begin{abstract}
South China Sea rated geopolitically, economically and strategically. It has been seen as the 'hot spot' that could be a source of tension in East Asia. Nicholas Spykman described the region as the 'Asiatic Mediterranean', while more recently, the term 'Chinese Caribbean' has been gaining favor and popularity, owing mainly to the ever-increasing importance of China in the region its efforts to play the role of a regional hegemon. The disputes in the South China Sea are complex, sometimes misunderstood, and it seems to be very difficult to propose more or less realistic scenarios for the foreseeable future.
\end{abstract}

Keywords: South China Sea, UNCLOS, balance of power, conflict, cold war, 'consociational' security order

The problem is not a new one, but has been gaining momentum and heating up gradually in recent years. Why? Because much of the contested areas in today's geopolitical reality lie not on dry land, but in the sea (the Arctic, East Asia). What is more, as Robert Kaplan stressed, in the $21^{\text {st }}$ century the demographic and economic axis of the world has shifted from Europe to the opposite end, where spaces between major population centers are overwhelmingly maritime ${ }^{2}$. Consequently, the maritime dimension of international relations is becoming an extremely important field of analysis.

The situation in the South China Sea had been quite stable for many years. Countries that are directly involved in the dispute had turned their attention to

1 This research was conducted while the author was on Taiwan Fellowship in National Chengchi University in Taiwan. The author wishes to thank the Taiwan Fellowship for supporting her research.

2 R. Kaplan, The South China Sea is the Future Conflict, "Foreign Policy", Sept/Oct 2011. 
domestic problems. The presence of the U.S. Navy in the area has been another stabilizing factor. Moreover, the People's Republic of China was not very active on the issue. For a long time, the PRC was unable to successfully push its own claims on a wider scale. Recently, however, the situation has changed - a fact that cannot be separated from recent changes in China's perception of its own security. It seems that China has shifted its attention from land-based military threats to challenges to its authority at sea. Consequently, the country has begun to defend its interests with more attention to the surrounding seas, particularly the South China Sea but also the East China Sea.

Many scholars - myself included - are of the opinion that we are witnessing an important shift in international relations. Going further, I think that the South China Sea (SCS) could be a case study for this important shift. I look at the SCS as a battleground, a place of struggle between a side that wants to keep its position and another that wants to change the status quo. What will come of old and new powers clashing? Will this interaction eventually become a springboard for conflict? What kind of power management should be recommended?

From my perspective as a researcher deeply involved in this topic, this article is only the beginning of a more complete and multifaceted research agenda that I would like to tackle in the nearest future.

\section{THE SUBJECT OF THE DISPUTE}

The South China Sea is a marginal sea in East Asia that forms part of the western Pacific Ocean. Covering a total area of over 3.5 million $\mathrm{km}^{2}$, it borders directly on the People's Republic of China (China), Brunei, Indonesia, Malaysia, the Philippines, Singapore, Vietnam, and the Republic of China (Taiwan). East Asia is an area that has been and continues to be plagued by tensions and conflicts, including full-scale war. The volatile areas are to be found in two subregions: the first is Northeast Asia, where potential zones of instability include the Korean Peninsula as well as the Kuril Islands, Taiwan, and East China Sea. The other is Southeast Asia, where the South China Sea is the main bone of contention ${ }^{3}$.

Within the SCS itself we can identify several areas of sensitivity. The first is the Gulf of Thailand, where conflicts arise between Malaysia and Thailand (regarding the status of the islands of Ko Kra and Ko Losin), and Cambodia and Vietnam (surrounding the island of Phú Quốc). Another nerve point is the Gulf of Tonkin, where two countries are involved - China and Vietnam. While most of the disputes were resolved by way of the 2000 Tonkin Gulf Agreement, there

3 See: E. Haliżak, Regionalny kompleks bezpieczeństwa Azji Pótnocno-Wschodniej. Warsaw: Scholar 2004 and J. Rowiński, Morze poludniowo-chińskie, region potencjalnego konfliktu $w$ Azji. Warsaw: Polish Institute of Foreign Affairs 1990. 
are still certain inconsistencies and a degree of friction regarding the Fishery Agreement ${ }^{4}$. The third sensitive area lies to the north of the Natuna Islands, a regency belonging to Indonesia, and the discord here stems from the overlap of the Chinese 'nine-dotted lines' and Indonesia's Exclusive Economic Zone. The fourth sensitive area is a triangle whose extreme points are formed by (1) the Pratas (Dongsha) Islands, controlled in practice by Taiwan but claimed by the People's Republic of China; (2) Macclesfield Bank (Zhongsha), controlled by China but claimed by Taiwan, the Philippines, and Vietnam; and (3) Scarborough Shoal, controlled by China but claimed by Taiwan and the Philippines. The fifth contentious archipelago is made up of the Paracel (Xisha) islands, which are at present effectively occupied by China but the object of a dispute between China, Taiwan, and Vietnam. Finally, the sixth and most hotly disputed area is that of the Spratly (Nansha) Islands, a six-way clash between the claims of sovereignty of China, Taiwan, Vietnam, Malaysia, the Philippines, and Brunei.

Beyond the states directly involved in these disputes, the geopolitical state of affairs in the South China Sea is no minor issue for the governments of the Republic of Korea and Japan due to concerns regarding the safe passage and supply of energy resources, and is also observed attentively by Australia, India, and particularly the United States, whose primary interests lie in freedom of navigation and advantageous geostrategic conditions to operate. Historical concerns are another factor that contribute considerably to the interest of these countries, as the Sea has been an area of vigorous activity in the political, economic, and cultural realms.

Maritime territorial disputes and the sometimes belligerent behavior of countries are a source of threat and encourage observers to define the region in terms of international security. Some of the most pressing issues include the negative feedback brought on by: (1) the exploitation of oil and natural gas reserves as well as the distribution of concessions for exploration and development among international corporations; (2) territorial disputes resulting from the actions of governments and national militaries such as the appropriation of islands, reefs, and atolls; (3) shows of force, use of force, or threats to use force (military exercises and movements of naval units usually associated with a war footing, takeovers of fishing and commercial vessels and their crews, piracy); (4) the relations between China and the United States, including the issue of Taiwan; and (5) differing interpretations of international maritime law.

There are many dimensions to the problem. More than that - there could be different approaches to the research itself.

${ }^{4}$ See: Yao Huang, Mingming Huang, Implementation of the Sino-Vietnamese Fishery Agreement: Mainly Chinese Perspective, "Beijing Law Review" 2013, vol. 4, no. 3, http://file.scirp.org/ pdf/BLR_2013093010471015.pdf; http://www.chinausfocus.com/peace-security/how-to-manage-china-vietnam-territorial-disputes/ [accessed: June 2015]

5 From 2013 ten-dotted line. 


\section{HISTORICAL DIMENSION}

The modern-day disputes in the South China Sea have clear historical precedents. It is a 'mediterranean' sea surrounded by land belonging to most of the ASEAN states, Taiwan, and China, which has historically conditioned it for a role as a channel of strong currents of cultural diffusion, international maritime trade, and interpretations of sovereignty very different from those in place today. In the past, legitimacy came less from physical control over territory and more from recognition by other rulers. In Southeast Asia, the mandala political model, adopted from Indian religious and political culture, featured political units which saw themselves as centres of networks and not as states with defined borders. Additionally, relations between them were fluid and some mandalas overlapped, so that less powerful centres might have had allegiances to more than one mandala ${ }^{6}$. Defined borders were not a matter of great concern at the time. This changed completely during the colonial era. Nevertheless, even then, the borders that were delineated were very imprecise and were used primarily as a tool to carve up the pie of colonial spheres of influence. The first document that aimed to achieve this was the Treaty of Saragossa (1529), which defined the respective spheres of influence of Spain and Portugal in Asia. It was the Portuguese, the first Europeans to sail into the waters of the basin, who gave the sea its name (Mar de China). The British, in turn, were the first to make claims to the Spratly Islands, which they considered part of the British Empire. The islands were named after Richard Spratly, the captain of the whaling ship Cyprus, who reported the existence of the islands in 1843. However, Great Britain did not protest or make competing claims when the French took over the islands - neither in 1930, when France declared sovereignty, nor in 1933, when they formally confirmed it. The parties that did object at the time were Japan and China. The former was concerned that the French takeover would imperil its trade interests ${ }^{7}$. Several years later Japan wrested control of the Spratly as well as the Paracel and Pratas islands, the start of an occupation that lasted until the end of World War II. Earlier, in 1895, Japan had taken Taiwan. From the surrender of American forces in the Philippines in 1942 until the of the war in the Pacific theater, the region was governed by a single state - Japan - for the first time in its history.

It should be noted that despite its weakness and fragility, the Chinese government also took measures to assert its claims to the area through the toolkit of the cartographer. The Review Committee for Land and Water Maps was set up

6 See: B. Hayton, The South China Sea. The Struggle for Power in Asia, Yale University Press, New Haven, London 2014, p. 15.

7 M. S. Samuels, Contest for the South China Sea, New York, London, Methuean Co Ltd, 1982, pp. 62-69, quoting B. Catley, M. Keiiat, Spratlys: The Dispute in the South China Sea, Ashgate, Aldershot, Brookfield, Singapore, Sidney 1997, p. 25. I lately wrote on rivalry in South China Sea in: A.W. Ziętek, Ewolucja sporów w regionie Azji i Pacyfiku, (in:) A. Jarczewska, J. Zajączkowski (ed.) Region Azji i Pacyfiku w latach 1985-2015, Scholar, Warszawa 2016. 
in 1933; that same year, the Newly-Made Chinese Atlas was published, with the Chinese border stretched down to $7^{\circ} \mathrm{N}$, encompassing the Spratly Islands ${ }^{8}$. In 1936, one of the most eminent Chinese geographers, Bai Meichu, published a map in his New China Construction Atlas which included a U-shaped line. A version of this map was copied and used to define China's historical island territories?.

Further attempts to pin down ownership of the islands and the sea were discussed during the Yalta Conference in 1945. On this occasion, China and France were making formal claims to sovereignty, while a peculiar kind of rivalry broke out between the contending states that consisted of placing symbols representing their respective sovereignties on contentious lands. In 1946, the newly formed nation of the Philippines threw in its lot by making territorial claims over the Spratly Islands. In 1947 the Geography Department of the Ministry of Internal Affairs drafted a list of new 'patriotic' names for all the islands in the $\mathrm{SCS}^{10} .1948$ was the year of the publication of a new Location Map of the South China Sea Islands as an addendum to the new Administrative Division Map of the Republic of China. These maps included a U-shaped line consisting of 11 dash-dots running from Taiwan to Borneo to the east, and to the Gulf of Tonkin to the north. The number of dash-dots later changed, initially to nine in 1953, when two of them were removed from the Gulf of Tonkin. In 2013 the Chinese State Bureau of Surveying and Mapping issued a new official map and added a tenth dash to the east of Taiwan, making clear that it too was firmly part of the national territory ${ }^{11}$.

The parties involved in the dispute are keen to refer to historical precedent in an effort to legitimize their territorial rights. The evidence they present to back up their claims is abundant and diverse. Su Hao of the Beijing Foreign Studies University notes that China's narrative highlights the fact that it was China that originally gave the sea and the islands their names, back in the era of the Han dynasty. Secondly, as early as the rule of the Western Jin dynasty (265-316 AD), China was already tapping into the natural resources of the sea. The sea itself was also well-known to fishermen, who had been mining its living resources for generations. China is earnest in underlining the sea's importance as a transport route, citing the expedition led by the well-known Ming-era explorer and diplomat Zheng He, who sailed through these waters on his way to East Africa. The palpable evidence cited by China largely comprises written sources and maps, as stated previously ${ }^{12}$. China's actions in this regard can be seen as offensive.

${ }^{8}$ B. Hayton, The South China Sea ..., p. 55.

${ }^{9}$ Ibidem, p. 56.

${ }^{10}$ Itu Aba was renamed Taiping Island, Spratly Island became Nanwei, the Paracel were renamed Xisha, the Pratas - Dongsha, and the Spratlys - Nansha

${ }^{11}$ See: New maps highlight South China Sea islands, http://www.china.org.cn/china/201301/12/content_27665192.htm [May 2015], China to issue new official map of 'full' territory, http:// www.taipeitimes.com/News/front/archives/2013/01/15/2003552554, (access: May 2015].

${ }^{12} \mathrm{Su}$ Hao, China's Position and Interest in the South China Sea: A Rational Choice in its Cooperative Policies, Center for Strategic and International Studies http://csis.org/files/publica- 
Although there is a dearth of archeological evidence for the activity of Chinese vessels on the South China Sea before the $10^{\text {th }}$ century, China is headstrong in its goal of proving its historical right to the entire basin at all costs. This conclusion is supported by the creation of the Underwater Archeological Heritage Center by China's State Administration of Cultural Heritage in 1986. In 1999, the Center announced that divers had discovered 1,500 relics dating from the year 907. It presented this as proof that the Chinese were the earliest inhabitants of the Paracel archipelago. In 2012, a Franco-Filipino expedition was dispatched to investigate a wreck on the Scarborough Shoal, but was halted by a Chinese Marine Surveillance ship whose captain ordered them to leave ${ }^{13}$.

China's actions and argumentation have been so commanding and persistent as to drown out the arguments presented by other countries, which by comparison seem to have little evidence to back their claims. With that said, if the contending parties are to refer to documents and maps to support their historical right to the islands, and if they are to bolster their arguments by referring to earlier agreements, then the group of interested actors might as well include former colonial states such as Great Britain and France, neither of which has ever formally renounced their claims to the Spratly archipelago.

\section{LEGAL DIMENSION}

The dispute in the South China Sea also possesses a legal dimension. The most common questions include: To whom do the contentious archipelagos belong according to international law? Do the islands possess the right to an Exclusive Economic Zone and continental shelf in accordance with the Convention on the Law of the Sea? What rules should be followed regarding the separation of maritime areas in this basin?

The lack of compelling evidence and legal foundations to resolve the problem of the islands' ownership has entailed that, for many years, the parties involved have acted according to the res nullius/terra nullius principle in international law. The most palpable consequence is the occupation of individual islands and the building of infrastructure on their land, which is later used to reinforce the case for sovereignty of the country responsible. China applies this approach a great deal. This strategy, previously described as the 'silkworm tactic' ${ }^{14}$ and today as 'salami slicing', consists of gradual encroachment on the territory of successive islands and today - the creation or simply construction of artificial islands in addition to

tion/110912_Hao_South_China_Sea.pdf, (access: June 2015)

${ }_{13}$ B. Hayton, The South China Sea..., p. 27.

${ }^{14}$ E. Haliżak, Spór o archipelagi na Morzu Południowochińskim. Znaczenie dla międzynarodowego prawa morza i bezpieczeństwa w regionie, in: E. Haliżak, R. Kuźniar (ed.), Prawo, instytucje i polityka w procesie globalizacji, Warszawa 2003, p. 182. 
a firm rejection of the open nature of the problem, while at the same time assuring all parties concerned of its desire to resolve the dispute peacefully. China uses the terra nullius principle in arguing for the legitimacy of the U-shaped line. In 2009 the Chinese government appended a map that contained the U-shaped line to a submission to the United Nations Commission on the Limits of the Continental Shelf. This marked the first time that the line had been used in an international setting ${ }^{15}$. It was also a response to the joint motion made by Vietnam and Malaysia, as well as a separate one by Vietnam, regarding the extension of the continental shelf beyond the 200-nautical mile zone.

Other principles of international law that China employs include uti possidetis ${ }^{16}$ and the estoppel doctrine ${ }^{17}$, particularly in disputes with Vietnam and with respect to the position of North Vietnam before 1975, when the North officially supported China's claims to the Spratly Islands. In a letter sent to the Chinese leadership, the government of the Democratic Republic of Vietnam wrote that it recognizes and approves the declaration made by the PRC in September 1958 with respect to "China's territorial sea"18. China also emphasizes that illegal acts do not generate rights, connecting its position to the country's grievances following World War II and the Cold War, when other countries took advantage of the weakness of the relatively young People's Republic to occupy territories that in China's view belonged to it ${ }^{19}$.

In the debate on the sovereignty of the islands and the sea in which they are situated, the different countries refer to the points outlined in the 1951 Treaty of San Francisco and the 1952 Treaty of Taipei. Article 2 of the first of these documents states that "Japan renounces all right, title and claim to the Spratly Islands and to the Paracel Islands" 20 . What is lacking is any indication of the party to whose benefit Japan is renouncing this right. Moreover, neither China (People's Republic of China) nor Taiwan (Republic of China) was a party to the treaty due to lack of agreement between the United States and Great Britain regarding who should represent Chinese interests. As such, the Treaty is not binding on either China or Taiwan. The next year, however, the government of the Republic of China (Taiwan) signed the Treaty of Taipei with Japan; Article 2 asserts that " $[i] t$ is recognized that under Article 2 of the Treaty of Peace with Japan signed at the

${ }^{15}$ B. Hayton, The South China Sea..., p. 59.

${ }^{16}$ A principle of international law stipulating that both sides involved in an armed conflict agree to end it, with all property and territory belonging to a given side up till then remaining in their hands, unless otherwise provided for by a treaty.

${ }^{17}$ Estoppel - broadly "not contradicting oneself," a rule that precludes a person or entity from making claims and assertions that contradict what they have previously stated or what has been previously established as fact.

${ }^{18}$ G. Hayton, The South China Sea..., s. 96.

${ }^{19} \mathrm{Su}$ Hao, op. cit.

${ }^{20} \mathrm{https}$ //treaties.un.org/doc/Publication/UNTS/Volume\%20136/volume-136-I-1832-English.pdf. 
city of San Francisco in the United States of America on September 8, 1951 (...), Japan has renounced all right, title and claim to Taiwan (Formosa) and Penghu (the Pescadores) as well as the Spratly Islands and the Paracel Islands"21. This is one of Taiwan's chief arguments in making its jurisdictional claims to the disputed territory. The weakness of these arguments is that the terms of agreement ceased to be in force after the 1972 Treaty of Peace and Friendship between Japan and the People's Republic of China. At present, Taiwan is occupying only one of the islands in the Spratly archipelago - Itu Aba (Taiping). This leads one to question whether, according to international law, functional control over one island justifies making claims to the entire archipelago?

The legal dimension of the dispute also includes the international legal regime - the United Nations Convention on the Law of the Sea (UNCLOS), signed on December 10, 1982 and ratified on November 16, 1994. Among other breakthroughs, the Convention created a classification system for territorial seas and related marine areas. It provides countries with the legal foundations to claim their right to marine territory, including the coastline, territorial seas, contiguous zones, Exclusive Economic Zones, and the continental shelf. The provisions of UNCLOS determine that coastal states could claim a territorial sea 12 nautical miles wide, an EEZ of 200 nautical miles, and an extended continental shelf beyond that. The provisions of UNCLOS led to the creation of the International Seabed Authority (ISA), the International Tribunal for the Law of the Sea (ITLS), and the Commission on the Limits of the Continental Shelf (CLCS). All of the countries directly taking part in the territorial disputes in the South China Sea are parties to the Convention. While the Convention regulates many issues, it remains uncertain whether it is possible to trace marine zones around islands. According to Article 121 of the Convention, "[a]n island is a naturally formed area of land, surrounded by water, which is above water at high tide"22. Furthermore, the island should be habitable. Therefore, rocks that do not fulfill the criterion of habitability by humans or provide adequate conditions for independent economic activity are not islands, and therefore it is not possible to delineate an EEZ and continental shelf around them ${ }^{23}$. In this context, should islands where army garrisons are stationed be treated as islands or as rocks? This seemingly simply semantic quandary pertains to most of the Spratly archipelago ${ }^{24}$. Another problem is that of the sovereignty and jurisdiction over the islands and the sea. The Convention refers to delimiting the territorial sea between countries whose coastlines lie opposite

${ }^{21} \mathrm{http}: / /$ www.taiwandocuments.org/sanfrancisco01.htm.

${ }^{22}$ United Nations Convention on the Law of the Sea, signed in Montego Bay on December 10, 1982 (Journal of Laws of the Republic of Poland, May 20, 2002), http://www.abc.com.pl/duakt/-/akt/dz-u-2002-59-543.

${ }^{23}$ Ibidem.

${ }^{24}$ R. Emmers, Maritime disputes in the South China Sea. Strategic and diplomatic status quo, in: Kwa Chong Guan, John K. Skogan (ed.), Maritime Security in the Southeast Asia, Routledge, London, New York 2007, p. 51. 
each other or which neighbor each other (Article 15), delimiting the Exclusive Economic Zone (Article 74), and delimiting the continental shelf (Article 83). However, it does not regulate actual sovereignty. It follows that it is effective as long as the territorial sovereignty of the islands does not elicit controversy. In the event that this condition is not fulfilled, the actions of any country in the area under dispute will generate diplomatic protest and, in extreme cases, a show of force or even an actual confrontation ${ }^{25}$.

It is in evidence that the belligerent behavior of the countries involved have the effect of escalating existing disputes - especially those of Vietnam and the Philippines with China. In May 2011 Vietnam and China accused each other of cutting seismic cables used for scientific measurements. In June 2011, Vietnam carried out military exercises in the region - a move that was harshly criticized and protested by China. 2012 saw further escalation of tensions. The subject of this face-off was the Scarborough Shoal, which is being claimed by the Philippines, China, and Taiwan. The Philippines took a three-pronged approach consisting of legal, political, and diplomatic measures. On the one hand, the country intended to present its case in an international tribunal, while at the same time seeking support for its position among fellow ASEAN countries and engaging in negotiations with China. For its part, China adopted a tactic of imposing restrictions such as canceling tourist trips from China to the Philippines, suspending chartered flights, throttling the import of bananas from the Philippines, and negative PR campaigns ${ }^{26}$. As a result, in January 2013, the Philippines submitted the case to arbitration proceedings in the Permanent Court of Arbitration (PCA). Due to the fact that UNCLOS clearly does not deal with reviewing individual claims to sovereign jurisdiction, resolving border disputes on the high seas, or ruling on historical rights of any nation to any territory, the justices are also unable to delineate marine borders themselves. The Philippines were not able to formally challenge the jurisdiction of any country over the Spratly Islands ${ }^{27}$. As such, in its Notification and Statement of Claims, the Philippines raised four main issues: (1) that the Chinese nine-dotted line lacks legal foundations, (2) that China can only claim ownership of a handful of rocks, but certainly not the islands scattered around the Scarborough Reef, (3) that Chinese construction on shallow underwater sands is illegal, and (4) that China flouts international law in harassing

${ }^{25}$ R. W. Smith, Maritime Delimitation in the South China Sea: Potentiality and Challenges, in: Nien-Tsu, Alfred Hu, Ted L. McDorman (ed.), Maritime Issues in the South China Sea. Troubled Waters or A Sea of Opportunity, Routledge, London, New York 2013, pp. 17-23.

${ }^{26}$ Shawn Shaw-fawn Kao, Scarborough Shoal Dispute, China's Assertiveness, and Taiwan's South China Sea Policy, "International Journal of China Studies" 2014, vol. 5, no. 1, p. 158.

${ }^{27}$ See UNCLOS Article 298, http://www.abc.com.pl/du-akt/-/akt/dz-u-2002-59-543, and China's declaration on the ratification of UNCLOS, http://www.un.org/depts/los/convention agreements/convention_declarations.htm, (access: June 2015). 
citizens of the Philippines on the high $\operatorname{seas}^{28}$. In response, the Ministry of Foreign Affairs of the PRC published a statement entitled Position Paper on the Matter of Jurisdiction in the South China Sea Arbitration, which asserted that UNCLOS does not apply in this case. Consequently, the Chinese government determined that it would neither acknowledge nor take part in the proceedings, arguing that China is within its rights to select peaceful means for resolving disputes, which is in accordance with the 2006 declaration on the ratification of UNCLOS ${ }^{29}$. Although the Chinese government completely originally ignored the activities and submission of its Filipino counterparts, the published position paper was certainly an assertion of its viewpoint, informal though it may have been. Experts point out that this publication was meant to soften international views of China, which is intent on chiseling out an image of a responsible state that respects the principles of international law and remains open to negotiation ${ }^{30}$. That said, in the same Position Paper, China stated that the arbitration tribunal had no jurisdiction to resolve the case, as it cannot judge on issues of sovereignty. If it dismisses concerns about jurisdiction, the tribunal will only then begin to hear the meat of the Philippines' argument regarding the validity of China's nine-dotted line and the question of the status of certain marine features in the $\mathrm{SCS}^{31}$. The Philippines have emphasized that the case is important not only for it but for the entire international community as well as for the rule of law in international relations ${ }^{32}$. It is quite interesting that China did not send any representatives to participate in or observe the hearing. According to China, the Philippines arbitration case is itself a violation of previous agreements, including the Declaration on the Code of Conduct on the South China Sea. In China's opinion, it is legally entitled to refuse to participate in the arbitration and even to ignore its judgement ${ }^{33}$. On July 12th 2016 Permanent Court of Arbitration in the Hague announced that China's

${ }^{28}$ P. A. Dutton, The Sino-Philippine Maritime Row: International Arbitration and the South China Sea, East and South China Sea Bulletin 2013, March 2013

${ }^{29} \mathrm{http}$ //www.cfr.org/territorial-disputes/chinese-ministry-foreign-affairs-position-papermatter-jurisdiction-south-china-sea-arbitration/p33978, (access: June 2015), see: Position Paper on the Matter of Jurisdiction in the South China Sea Arbitration Initiated by the Republic of the Philippines, http://www.fmprc.gov.cn/mfa_eng/wjdt_665385/2649_665393/t1217147.shtml, (access: June 2015).

${ }^{30}$ M. Waxman, Legal Posturing and Power Relations in the South China Sea, Asia Maritime Transparency Initiative, January 21, 2015, http://amti.csis.org/legal-posturing-and-powerrelations-in-the-south-china-sea/ (access: June 2015).

${ }^{31}$ S. Tiezzi, In the Philippines' South China Sea Case, Is International Law on Trial?, "The Diplomat" July 14, 2015, http://thediplomat.com/2015/07/in-the-philippines-south-china-seacase-is-international-law-on-trial/ (access: July 2015).

${ }^{32}$ P. Parameswaran, Does the Philippines 'South China Sea Case Against China Really Metter?, The Diplomat, July 8, 2015, http://thediplomat.com/2015/07/does-the-philippines-south-china-sea-case-against-china-really-matter/ (access: July 2015).

${ }^{33}$ China opposed Philippines arbitration case, http://english.cntv.cn/2015/07/07/VIDE14 36267888563988.shtml, (access: July 2015). 
expensive claims in the SCS are illegal. Beijing dismissed the ruling. This situation will probably inflame tension in the South China Sea.

\section{GEOPOLITICAL AND GEOSTRATEGIC DIMENSION}

The geopolitical and geostrategic importance of the South China Sea is difficult to overlook and difficult to overestimate. The islands situated in this basin constitute a formidable base for the construction of military fortifications and airports. It is, therefore, small wonder that the states of the region attach great importance to the islands, cognizant of the fact that whoever controls the sea will simultaneously wield virtually unlimited control over one of the world's most heavily frequented sea routes. As Robert D. Kaplan puts it, 'anyone who speculates that with globalization, territorial boundaries and fights for territory have lost their meaning should behold the SCS ${ }^{34}$.

The position and actions of the PRC and those of the United States are crucial in these disputes. Following a period of relative calm, the situation escalated in the 1990s due to a combination of increased assertiveness by the Chinese government and a change in its perception of security. Territorial threats no longer originated from the mainland, instead taking on a new marine dimension. Furthermore, the region possesses strategic importance for China due to the sizable Chinese diaspora that populates the countries of Southeast Asia and because of the strong, cross-cutting economic ties that bind all the countries in the region. Years ago, Nicholas Spykman described the region as the 'Asiatic Mediterranean', though recently it has frequently been referred to as the 'Chinese Caribbean', in large part due to the rise of China as a regional hegemon ${ }^{35}$. Nevertheless, the SCS in not exactly the same as the Caribbean, which was far from the main sea routes of the world, while the SCS is at their confluence and their heart ${ }^{36}$.

In 2010, one of the top officials in the Chinese government, speaking outside of his formal capacity, described the SCS region as a 'core interest' - a term previously reserved for Taiwan and Tibet. If true, this suggests that China will treat the interference of third parties as a violation of its territorial integrity. Moreover, the SCS is beckoning for China given that it may hold the key to is geostrategic future. Functional dominion over the sea paves the way for China to become a true two ocean navy, in the Western Pacific and the Indian Ocean ${ }^{37}$. In July 2010, U.S. Secretary of State Hillary Clinton took advantage of her participation

${ }^{34}$ R. D. Kaplan, Asia's Cauldron. The South China Sea and the End of a Stable Pacific, Random House, New York 2015, p.13.

${ }^{35}$ Tetsuo Kotani, Why China wants South China Sea, "The Diplomat", http://the-diplomat. com/2011/07/18/why-china-wants-the-south-china-sea/ (access: June 2015).

${ }^{36}$ R. D. Kaplan, Asia's Cauldron..., p. 14.

${ }^{37}$ Ibidem, p. 20. 
in the ASEAN Regional Forum to convey that it is in the U.S.'s national interest to guarantee freedom of navigation in these waters. She further described the situation in the South China Sea as a cornerstone and condition of security in the region $^{38}$. This statement opened the book on a new strategy employed by the U.S., referred to as the 'American pivot' towards Asia and the Pacific or the 'strategy of rebalancing ${ }^{39}$. This new approach is seen as a response to the increasingly assertive position of China as well as an attempt to adapt to an expected transformation of relations and division of power in the international arena ${ }^{40}$. In practice, the strategy is realized through the strengthening of existing alliances with countries in the region, including Japan, South Korea, Australia, the Philippines, and Thailand, as well as establishing and expanding collaboration with countries such as Indonesia, Vietnam, New Zealand, and Singapore. In 2012, during the $14^{\text {th }}$ Asia Security Summit (the so-called Shangri-La Dialogue), U.S. Secretary of Defense Leon Panetta stated that by 2020, $60 \%$ of the Navy's military capacity would be distributed in the Asia-Pacific region ${ }^{41}$. The interests and security of the United States elevate freedom of navigation and the Navy's right to safely sail in international waters and straits above all. China's activity in the region and its unilateral assertion of sovereign jurisdiction over almost the entire basin is thus viewed as a threat to free navigation in the future.

The Chinese island-building program in the disputed areas of the South China Sea is generating much emotion currently. Admiral Harry B. Harris, Jr., presently serving as Commander of the U.S. Pacific Command, has described this tactic as akin to building a "great wall of sand" ${ }^{2}$. Granted, projects of this kind are nothing new in the region - both Vietnam and the Philippines have engaged in similar efforts at different points in time. What is worrisome is the scale of the Chinese operation. It should also be examined from the broader perspective - namely Xi Jinping's 'One Belt, One Road' project, first revealed in 2013 and officially unveiled in March 2015. The project involves reinventing two trade routes: the Silk Road Economic Belt and the Maritime Silk Road. Its purpose is to reinforce China's position on land and sea and to strengthen its relations with countries such

${ }^{38}$ Nong Hong, US-China Perception Gap on the Messy South China Sea Disputes: Assessment of Post-2009 Developments, China US Focus, September 2011, http://www.chinausfocus. $\mathrm{com} /$ slider/u-s-china-perception-gap-on-the-messy-south-china-sea-dispute-assessment-of-post2009-developments/, (access: June 2015).

${ }^{39}$ See: H. Clinton, America's Pacific Century, "Foreign Policy" 2011, 189 (1), http://foreignpolicy.com/2011/10/11/americas-pacific-century/ (access: June 2015).

${ }^{40}$ M. Dian, The Pivot to Asia, Air-Sea Battle and contested commons in the Asia Pacific, The Pacific Review 2015, vol. 28, no. 2, p. 239.

${ }^{41}$ L. Panetta, The US Rebalance Toward the Asia Pacific, http://www.iiss.org/-/media/Images/Events/conferences $\% 20$ from $\% 20$ import/the $\% 20$ shangri\%20la $\% 20$ dialogue/shangri $\% 201 \mathrm{la} \% 20$ dialogue $\% 202012 /$ speeches/first $\% 20$ plenary\%20session/66624.pdf (access: June 2015).

${ }^{42}$ The Washington Times, http://www.washingtontimes.com/news/2015/mar/31/china-creating-great-wall-of-sand-near-disputed-is/ (access: June 2015). 
as Cambodia, Malaysia, Sri Lanka, and Pakistan ${ }^{43}$. This also implies that China is declaring its readiness to take on greater responsibility and make a greater contribution to global development. It is also interpreted as a move away from Deng Xiaoping's principle of 'keeping a low profile' - a move illustrative of Xi Jinping's new style of diplomacy. Not everyone, however, sees China's intensified activity in the same positive light. It also provokes unease and concern in the United States, whose political elite fears that their own country's position on the unofficial playing field will be compromised.

The South China Sea lies at the confluence of key maritime trade routes that connect East Asia with the Indian Ocean and the Middle East. The Strait of Malacca is of absolutely vital importance here, as it is through this chokepoint that the shortest supply route of petroleum reaches one of the most dynamically expanding economies in the world. It is also a key artery for the energy resource supply of Japan and South Korea. The Strait of Malacca has a great deal of historical importance. In the past, Malacca was a major regional entrepôt. The Portuguese realized that transporting spices and other luxury products from Asia to Europe in a single sea journey was cheaper and safer than using traditional land routes. In their modern carracks, they were able to carry cargo as well as cannons and quickly came to dominate international trade. Thanks to this, they took control of Malacca in 1511 and remained there for the following 130 years ${ }^{44}$. A dominant position in the region was, therefore, in the past, predicated on who controlled the Strait, which successively fell into the hands of the Portuguese, the Dutch, the British, and the Japanese. Today it is still a place of crucial geostrategic importance - and therefore a place that is extremely sensitive to threats stemming from political instability in the region, terrorism, and piracy. The sole guarantee of safety and security in this case would be international collaboration and the creation of common rules regulating the behaviour of all sides.

\section{RESOURCE DIMENSION}

The South China Sea basin is rich in natural resources, both renewable and non-renewable. Many researchers believe that the political situation in the South China Sea is conditioned by the growing demand for energy resources. This view is endorsed by Sigfrido Burgos Cáceres ${ }^{45}$, who believes that high demand for energy resources drives China's assertive behavior in the region. Some confirmation of this can be found in the position expressed by the National Energy Admin-

${ }^{43}$ W. Yale, China's Maritime Silk Road Gamble, “The Diplomat" 2015, April 22, http://thediplomat.com/2015/04/chinas-maritime-silk-road-gamble/ (access: June 2015).

${ }^{44}$ B. Hayton, The South China Sea ..., p. 31.

${ }^{45}$ See: S.B. Cáceres, China'Strategic Interest in the South China Sea. Power and Resources, New York, Routledge 2014. 
istration of China (NEAC), according to which the South China Sea possesses considerable reserves of undersea energy resources. Access to these resources is important due to the ballooning energy needs of China's economy.

If we examine the known facts, however, we see that while the South China Sea does hold reserves of oil and natural gas, the data on their volume are not conclusive. China harbors an optimistic view of available resources, while American sources estimate the total volume of oil reserves to be much lower ${ }^{46}$. The same discrepancy holds for natural gas, though there is greater overlap here as far as estimated reserves are concerned. According to the Energy Information Administration, the cumulative reserves of extractable oil and natural gas in the region amount to around 11 billion barrels of oil and about 58 billion cubic meters of natural gas. Most of these reserves are located near territory belonging to China, Malaysia, Brunei, Indonesia, Thailand, Vietnam, and the Philippines, i.e., areas where each country's jurisdiction is not a contentious issue. The Agency believes that these reserves are similar in size to those of Mexico and constitute about two-thirds of known European reserves (excluding Russia). However, the Sea may contain additional pools of oil located in disputed areas near the northeastern part of the Spratly Islands, in the vicinity of Reed Bank, while possible untapped reserves of natural gas may be found near the Paracel Islands, which are also disputed. Exploration of these resources is not currently feasible and probably not remunerative, due to both the geopolitical circumstances (territorial disputes) and concerns of a purely technical and geological nature ${ }^{47}$. Tensions and disputes pertain primarily to the exploration of oil and gas reserves that lie under the seabed as well as concessions handed out to international corporations for the exploration and surveying of the seabed. As recently as the 1990s, China's position on exploration was rather restrained. During a tour of Southeast Asia in 1990, Chinese Premier Li Peng stated that China was "ready to join efforts with Southeast Asian countries to develop the Nansha Island while putting aside, for the time being, the question of sovereignty". This approach derived from the understanding that the situation was complicated enough to take years, if not decades, to resolve. The declaration can also be seen as an attempt to buy time or as a decoy tactic. However, in reality Premier Li's proposal was rather an "empty posturing". That said, Hayton speculates that "[t]here was more than simply postponing disagreement. [The strategy's] full formulation had three elements: sovereignty is ours, set aside disputes, purpose joint development." According to Hayton, this meant that any 'other country wishing to develop maritime resources within the 'U-shaped line' would either have to recognize Beijing's territorial claims or directly challenge

${ }^{46}$ See: US Energy Information Administration, http://www.eia.gov/countries/regions-topics. cfm?fips=WOTC, (access: June 2015).

${ }^{47}$ Contested areas of South China Sea likely have few conventional oil and gas resources, http://www.eia.gov/todayinenergy/detail.cfm?id=10651 (access: June 2015). 
Beijing's physical presence ${ }^{48}$. While it must be said that Beijing's starting position was rather weak, it improved with every passing year. In the meantime, drilling and surveying work on the seabed became politicized, as the fine line between politics and business began to blur. In the years that followed, China began to put pressure on international corporations to withdraw their investments from the other countries in the region in exchange for lucrative contracts in China. They also sporadically used veiled threats to communicate to the firms that China did not guarantee the safety of the crews working on the oil platforms. Explorative drilling in the basin became a considerable economic liability due to uncertainty regarding the volume of available reserves and difficulties in extracting them.

The South China Sea also abounds in renewable living resources. It is thought that the fisheries in the region supply $25 \%$ of the total consumption of fish for the inhabitants of the region. Aside from fish, the Sea is rich in aquatic plants, including seaweed, mollusks, shells, pearls, and guano, the odorless fertilizer commonly used in gardening ${ }^{49}$. Fishing constitutes an important sector of the economy for all the countries in the region. Access to living resources is therefore another bone of contention for the countries involved in the dispute, hence the tensions and conflicts that have erupted with some regularity in recent years. In 2012, the Filipino Navy attempted to detain and arrest fishermen on board Chinese fishing vessels near Scarborough Shoal, which led to a two-month-long freezing of relations between China and the Philippines ${ }^{50}$. It is important to notice that the contending parties are keen to use protection of marine resources as justification for their territorial claims.

Conflict analysis in the South China Sea brings up several fundamental questions. First, can these disputes truly escalate into armed conflict among the states involved? Second, are the instruments and rules of conduct employed in the region effective in conflict management and will they enable the sides to achieve common ground - or will the conflict simmer in perpetuity? Third, will the countries involved in the disputes respect international law and act in accordance with the accepted rules and regulations, or will they take an instrumental, ad-hoc approach to the tools it offers, breaking them at their whim and fancy?

\section{SCENARIOS OF POWER MANAGEMENT}

Considering the questions formulated at the beginning and the fact that the South China Sea is a hotbed of rivalry among not only the countries of the region,

${ }^{48}$ B. Hayton, The South China Sea ..., p. 122.

${ }^{49}$ See: M. J. Valencia, J. M. Van Dyke, N. A. Ludwig, Sharing the Resources of the South China Sea, University of Hawaii Press 1999.

${ }^{50} \mathrm{http} / / / w w w . a l j a z e e r a . c o m / p r o g r a m m e s / 101$ east/2012/07/201273093650328417.html(access: June 2015). 
but perhaps especially China and the United States, it is possible to propose three scenarios based on realist theory in international relations. These scenarios reappear across many articles, reports, and opinion pieces.

The first scenario involves conflict between China and the United States. This scenario currently seems to be rather unlikely ${ }^{51}$, though it cannot be ruled out completely due in no small part to the United States' strategy in the region, which the PRC sees as an attempt to encircle it ${ }^{52}$. In effect, we are witnessing a process of increasing militarization, though the military potential of the two countries is still disproportionate. According to SIPRI (2014), in military spending alone, the budget of the U.S. dwarfs that of China, with $\$ 610$ billion against the latter's 216 billion ${ }^{53}$. Strong economic links between these two countries also have a stabilizing effect, as does the specter of losses in trade amounting to around $\$ 5$ billion annually in the event of a conflict, representing the total estimate of international trade flows in the region. What cannot be ruled out is the threat of armed incidents involving the two countries within the Chinese Exclusive Economic Zone. This was in evidence in 2013, 2014, and 2015 when a number of incidents involved the deployment of both countries' navies and spy planes.

According to the 2015 Global Risk Report, there is a strong likelihood that the modern world is at the dawn of a new era of strategic rivalry in which the great global powers as well as strong regional players in the Asia-Pacific (e.g. China, the United States, Japan, and Russia) will play a leading role. The report emphasized that there has been a spike in nationalist sentiment among the nations of the region, which may narrow the space for dialogue and collaboration in the future. Nationalism in the region may also be stoked by internal problems and frustrations, which may then be channeled outward. In his article in The Wall Street Journal, David Shambaugh predicts an endgame to communist rule in China ${ }^{54}$. Does this mean that China will be more prone to aggressive reactions to external challenges to its authority? At the same time, the authors of the report stress that modern conflict does not necessarily have to involve a prominent physical, armed dimension, but may come in the form of economic rivalry, cyberattacks and cyberespionage, or the struggle for certain values and worldviews. Conflicts may also be facilitated by the lack of international governance mechanisms or their relative weakness, which curbs the ability of states to undertake joint operations

${ }^{51}$ See: Scenarios of China-American relations, Z. J. Pietraś, Ewolucja syntetycznej międzynarodowej roli ChRL, in: K. Iwańczuk, A. Ziętek (ed.), Chiny w stosunkach międzynarodowych, Wydawnictwo UMCS, Lublin 203, pp. 100-101, H. Kissinger, The Future of U.S.-Chinese Realtions. Conflict is a Choice, Not a Necessity, Foreign Affairs 2012, vol. 91, no. 2

${ }^{52}$ See A. J. Nathan, A. Scobell, How China Sees America. The Sum of Beijing's Fears, Foreign Affairs 2012, September/October.

${ }^{53} \mathrm{http} / / /$ www.sipri.org/research/armaments/milex/milex_database, (access: June 2015).

${ }^{54}$ D. Shambaugh, The Coming Chinese Crackup, "The Wall Street Journal”, March 6, 2015. 
or initiatives. Such initiatives do exist in the region, but their effectiveness and returns are questionable at best ${ }^{55}$.

The second scenario is that of a new cold war, marked by intense, simmering animosity that never boils over into open conflict. Joseph S. Nye writes that a cold war reveals the dynamics of decision-making in foreign policy, focused around two poles: to deter or to restrain ${ }^{56}$. The first option finds expression in military buildups, forging alliances, and saber-rattling. The American 'rebalancing strategy' can also be interpreted in this way in that it entails visible engagement in the region and expanded collaboration with the state actors who operate within it. Such collaboration can have a strong security or military component, as evidenced by defense pacts with Australia, Japan, New Zealand, the Philippines, South Korea, and Thailand. The U.S. is also working on expanding and deepening existing alliances with Singapore, Indonesia, Malaysia, and India, and carrying out incipient moves to develop military collaboration with a democratizing Myanmar $^{57}$. At the 2015 Shangri-La Dialogue, U.S. Secretary of Defense Ashton Carter reiterated his country's commitment to military support for its allies in the region ${ }^{58}$. Military exercises and drills are conducted in the region regularly, recently approaching the disputed areas as well as China's newly-constructed artificial islands. The most recent round of exercises, in April and June of 2015, involved U.S., Japanese, Australian, and Filipino forces. On July 18, 2015 Admiral Scott Swift, Commander of the U.S. Pacific Fleet, joined a seven-hour surveillance flight over the contentious parts of the SCS. This was welcomed enthusiastically by U.S. allies in the region. Moreover, in an interview with reporters in Manilla, Swift assured U.S. allies that American forces were well-equipped and ready to respond to any contingency in the sea ${ }^{59}$.

The ongoing process of militarization in the Asia-Pacific region also involves increased activity on the part of China, which is building up its Navy in response to a change in strategy from coastline defence to defence on territorial and high

${ }^{55}$ Global Risks 2015 10th Edition, http://www3.weforum.org/docs/WEF Global Risks 2015_Report15.pdf, (access: June 2015), also see: A. Ziętek, Territorial disputes over the South China Sea, (in:) Border Conflicts in the Contemporary World, A. Moraczewska, W. Janicki (ed.), Wydawnictwo UMCS, Lublin 2014.

${ }^{56}$ J. S. Nye Jr., Konflikty międzynarodowe. Wprowadzenie do teorii i historii, Wydawnictwa Akademickie i Profesjonalne, Warszawa 2009, p. 169.

${ }^{57}$ Militarization of Asia-Pacific: America revives and expands cold war military alliances against China, http://www.globalresearch.ca/militarization-of-asia-pacific-america-revives-andexpands-cold-war-military-alliances-against-china/31336, (access: June 2015).

${ }^{58}$ The Philippines to the United States: We want you back, Foreign Policy 2015, http://foreignpolicy.com/2015/06/01/philippines-china-military-carter/ (access: June 2015).

${ }^{59} \mathrm{http}: / / \mathrm{www} . u s n e w s . c o m / n e w s /$ world/articles/2015/07/19/us-pacific-fleet-chiefjoins-surveillance-of-south-china-sea?utm_source=Sailthru\&utm_medium=email\&utm term $=\% 2$ ASituation\%20Report\&utm_campaign=SitRep0720 (access: July 20, 2015). 
seas alike ${ }^{60}$. China has over sixty submarines and will have around seventy-five in the next few years, which is slightly more than the United States. As such, by the late 2020s China will have more warships in the Western Pacific than the U.S. Pacific Fleet ${ }^{61}$. The militarization process allows the countries of the region to treat it as an excellent future defence market ${ }^{62}$. According to SIPRI, of the fifteen largest defense budgets in the world, seven belong to countries in the Asia-Pacific: the United States, China, Japan, South Korea, India, Australia, and Russia ${ }^{63}$. This may stimulate the closed loop of threat and create security dilemmas that may ultimately heighten tensions further, especially since none of the countries embroiled in the disputes in the South China Sea seem to be willing to withdraw from or modify their position significantly.

On the other hand, the restrain strategy would be largely economic in nature in the case of the rivalry between the U.S. and the PRC. The Trans-Pacific Partnership (TPP) and the newly constituted Asian Infrastructure Investment Bank (AIIB) illustrates this on the part of the U.S. and China, respectively. That said, it is too early to conclusively state whether these are indeed signs of rivalry or, as in the case of the AIIB, whether the goal is to ensure the availability of resources for crucial infrastructural development in Asia. Thus, some analysts conclude that these actions cannot be classified into the familiar pigeonhole of Sino-American rivalry ${ }^{64}$. The tactic of holding back the enemy also possesses an ideological dimension, difficult though it is to speak of open ideological rivalry of the magnitude that existed between the U.S. and the USSR. There are, however, opposing worldviews with regard to certain core values, including human rights and the protection of intellectual property.

The third scenario is a balance of power, understood as the desire of the countries involved to stem excessive concentration of power in the hands of any given state. In my view, this is the most likely scenario, and one whose contours are already visible today. To a large extent, the debate here revolves around the power of China as well as that of other regional players. The balance of power scenario assumes that if any single country begins to clearly dominate over the others, the stage will be set for alliance-forming among the dominated.

${ }^{60}$ See: J. Symonides, Modernizacja i rozbudowa sił morskich Chin. Czy początek wyścigu zbrojeń na Pacyfiku?, „Kwartalnik Bellona” 2013, no. 3.

${ }^{61}$ R. Kaplan, Asia's Cauldron..., p. 34-35.

${ }^{62}$ G. Till, J. Chan, Introduction: naval modernisation in the South - East Asia: nature, causes and consequences, in: G. Till, J. Can (ed.), Naval Modernisation in South-East Asia: Nature, causes and consequences. Routledge, London, New York 2014, p. 3.

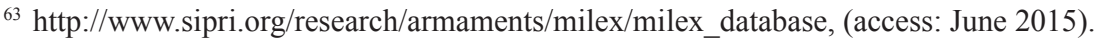

${ }^{64}$ P. Parameswaran, Is This Japan's New Challenge to China's Infrastructure Bank?, "The Diplomat" 2015, May 25, http://thediplomat.com/2015/05/is-this-japans-new-challenge-to-chinas-infrastructure-bank/ (access: June 2015), Idem, The Truth About China's 'Big, Bad'Infrastructure Bank, "The Diplomat" 2014, October 16, http:/thediplomat.com/2014/10/the-truth-aboutchinas-big-bad-infrastructure-bank/ (access: June 2015). 
Henry Kissinger believes that the rise of China will trigger a search for balance on the part of the Chinese government between the Sinocentric policies of the past and the country's role in the contemporary new Westphalian order (Late Westphalian order A.Z.). At the same time, he emphasizes that while China and the U.S. may differ considerably on issues like democracy and human rights, avoidance of conflict is in their common interest. As such, relations between the two superpowers may be less at risk than China's relations with its Asian neighbors, all of which profess a vision of themselves as developing countries. This volatile brew may, in effect, carry existing disputes to the brink of armed conflict ${ }^{65}$.

The presence and activity of the United States in the region is perceived by China as a threat, to which it will respond with a balancing act. Likewise, the rise of China is provoking fears in the other countries of the region in the context of the precarious situation in the South China Sea. We may therefore expect that some countries will choose the bandwagon strategy in response. On the one hand, the other parties to the conflict are trying to develop one voice in the struggle with China, under the banner of ASEAN. However, recent ASEAN summits have made it apparent that reaching a consensus on this issue will not be simple. The address by the chairman of the summit during its most recent iteration, on April 27, 2015, did not name China directly, but it did underline that actions whose goal is to build artificial islands in the region undermine mutual trust and stability in the South China Sea. At the summit, the Philippines considered it pivotal to mobilize other countries in Southeast Asia against China's maneuvers in the area, but its attempts proved fruitless. This may suggest that the countries of the region are indeed very divided on the issue ${ }^{66}$. Some countries in the region seem to prefer a strategy of joining forces with stronger actors, whether it be the United States (Vietnam, Thailand, Philippines, Indonesia) or China (Cambodia, Laos, Myanmar), or choose to remain relatively neutral (Malaysia, Brunei, Singapore).

\section{THE FOURTH SCENARIO}

In an essay, Amitav Acharya proposed different or alternative conceptualization of the Asian security order. It is one he calls a 'consociational' security order, one which draws from different theoretical approaches: defensive realism, institutionalism, and consociational theory in comparative politics. He noted that while the rise of China is reshaping Asia's military balance, the region has also witnessed equally important and long-term changes, especially in the realm of economic

${ }^{65}$ See: H. Kissinger, World Order, Penguin Press, New York 2014.

${ }^{66}$ P. Paremeswaran, What did the $26^{\text {th }}$ ASEAN Summit achieve?, "The Diplomat", http://thediplomat.com/2015/04/what-did-the-26th-asean-summit-achieve/, [accessed June 2015]. 
interdependence, multilateral institutions, and domestic politics ${ }^{67}$. I think that this scenario is more complex and not as one-dimensional as the scenarios drawn from realism. It captures a wider range of determinants of Asian security, focusing not only on the competition between China and the U.S. Instead, it emphasizes the regional context of the implications of China's rise rather than relations between great powers. This option proposes a mixed scenario of conflict and stability in which we can talk about different layers of security. According to Acharya, this vision "present [s] an alternative between the extremes of anarchy that represent Europe's past as Asia's future on the one hand and a security community that renders war unthinkable on the other (Europe's present as Asia 's future)" ${ }^{\prime \prime}$.

\title{
CONCLUSION
}

Summing up, we can observe a real geostrategic gambit in the region. Sustaining this will not be an easy solution for the future. Moving forward, perhaps the best choice for all the countries involved is maintaining the status quo - but how long can it be maintained? Especially since the situation in the region as well as the internal situation (political and economic) in the countries involved (like China) is very fragile?

\section{MORZE POŁUDNIOWOCHIŃSKIE. RYWALIZACJA I MOŻLIWE SCENARIUSZE}

\begin{abstract}
Abstrakt. Morze Południowochińskie ostatnio stało się rejonem rywalizacji między Chińską Republiką Ludową a Stanami Zjednoczonymi Ameryki. Sytuacja w regionie może ona mieć wpływ na kształtowanie się nowego ładu międzynarodowego i na nowy układ sił w regionie Azji i Pacyfiku. W związku z tym można sobie postawić następując pytania: jaką rolę w nowym ładzie będą odgrywały Stany Zjednoczone, a jaką Chiny? Czy faktycznie jesteśmy świadkami osłabienia pozycji USA i wzmacniania pozycji Chin? Czy rywalizacja to doprowadzi do bezpośredniego konfliktu militarnego, czy raczej będziemy świadkami eskalacji napięcia? Czy w regionie będzie się kształtowała nowa równowaga sił?
\end{abstract}

Słowa kluczowe: Morze Południowochińskie, UNCLOS, równowaga sił, zimna wojna, porządek międzynarodowy, bezpieczeństwo

${ }^{67}$ See: A. Acharya, Power Shift or Pardigm Shift? China's Rise and Asia's Emerging Security Order, "International Studies Quarterly" 2014, no. 58.

${ }^{68}$ A. Acharya, Power Shift..., p. 171. 